\title{
The $A \beta$ protofibril selective antibody mAb158 prevents accumulation of $A \beta$ in astrocytes and rescues neurons from $A \beta$ - induced cell death
}

Sofia Söllvander ${ }^{1}$, Elisabeth Nikitidou', Linn Gallasch', Marlena Zyśk', Linda Söderberg², Dag Sehlin', Lars Lannfelt ${ }^{1}$ and Anna Erlandsson ${ }^{1 *}$

\begin{abstract}
Background: Currently, several amyloid beta (AB) antibodies, including the protofibril selective antibody BAN2401, are in clinical trials. The murine version of BAN2401, mAb158, has previously been shown to lower the levels of pathogenic $A \beta$ and prevent $A \beta$ deposition in animal models of Alzheimer's disease (AD). However, the cellular mechanisms of the antibody's action remain unknown. We have recently shown that astrocytes effectively engulf $A \beta_{42}$ protofibrils, but store rather than degrade the ingested $A \beta$ aggregates. In a co-culture set-up, the incomplete degradation of $A \beta_{42}$ protofibrils by astrocytes results in increased neuronal cell death, due to the release of extracellular vesicles, containing $\mathrm{N}$-truncated, neurotoxic $\mathrm{A} \beta$.
\end{abstract}

Methods: The aim of the present study was to investigate if the accumulation of $A \beta$ in astrocytes can be affected by the $A \beta$ protofibril selective antibody mAb158. Co-cultures of astrocytes, neurons, and oligodendrocytes, derived from embryonic mouse cortex, were exposed to $A \beta_{42}$ protofibrils in the presence or absence of mAb158.

Results: Our results demonstrate that the presence of mAb158 almost abolished $A \beta$ accumulation in astrocytes. Consequently, mAb158 treatment rescued neurons from A $\beta$-induced cell death.

Conclusion: Based on these findings, we conclude that astrocytes may play a central mechanistic role in anti-A $\beta$ immunotherapy.

Keywords: Alzheimer's disease, Amyloid- $\beta$, Antibody, Clearance, Astrocyte, Neuron

\section{Background}

Alzheimer's disease $(\mathrm{AD})$ is a devastating neurodegenerative disease, affecting millions of people worldwide. Clinically, $\mathrm{AD}$ is characterized by the progressive loss of neurons, which typically leads to severe impairments in cognitive functions, including learning and memory. Key pathological features of $\mathrm{AD}$ include the formation of amyloid beta $(\mathrm{A} \beta)$ plaques, neurofibrillary tangles, neuronal loss, and reactive gliosis.

Due to its hydrophobic nature, the $A \beta$ peptide has a strong propensity to aggregate and form both soluble $A \beta$

\footnotetext{
* Correspondence: anna.erlandsson@pubcare.uu.se

${ }^{1}$ Department of Public Health and Caring Sciences, Molecular Geriatrics,

Rudbeck Laboratory, Uppsala University, Uppsala, Sweden

Full list of author information is available at the end of the article
}

aggregates and insoluble $A \beta$ fibrils, which eventually deposit as plaques. Results from many research groups indicate that the widespread neuronal dysfunction in the $\mathrm{AD}$ brain is caused by soluble $\mathrm{A} \beta$ oligomers/protofibrils, rather than the insoluble $A \beta$ fibrils [1-3]. How the soluble $A \beta$ aggregates exert their toxic effects is however not clear, but they have been shown to inhibit long-term potentiation and to impair synaptic function and plasticity $[1,4-10]$. Moreover, results from biophysical studies indicate that $\mathrm{A} \beta$ oligomers may perform their toxic function through interactions with the lipid bilayers, since membrane interaction can promote formation of toxic A $\beta$ species [11-13].

Immunotherapy has emerged as a promising method to reduce $A \beta$ pathology. Due to their toxic nature, 
soluble $A \beta$ aggregates have been suggested to be an especially attractive immunization target. Currently, several anti-A $\beta$ antibodies, including the $A \beta$ protofibril selective monoclonal antibody BAN2401, are evaluated as $A D$ therapeutics [14]. Importantly, prefibrillar forms of $A \beta$ have been shown to be the predominant species of soluble $A \beta$ aggregates in both transgenic mice and human $\mathrm{AD}$ brains [15]. In animal models of $\mathrm{AD}$, the murine version of BAN2401, mAb158, lowers brain levels of soluble $A \beta$ protofibrils and prevents $A \beta$ deposition [16], but the underlying mechanisms and the role of different cell types for its action remain to be elucidated.

There is compelling evidence that $A \beta$ pathology is closely associated with inflammation, and reactive astrocytes and microglia are situated tightly around the plaques [17]. Being the most abundant glial cell type in the nervous system, astrocytes play an important role in maintaining brain homeostasis [18]. Their functions include metabolic support of neurons, modification of synapse signaling, recycling of neurotransmitters, bloodbrain barrier regulation, and glymphatic clearance [1820]. In addition, astrocytes respond to neurodegenerative disorders, including $\mathrm{AD}$, through astrogliosis, a process in which they convert to a reactive inflammatory state $[21,22]$. The complex role of astrocytes in the pathological brain is largely depending on their release and uptake of substances from the microenvironment that they share with the neurons [18]. For example, astrocytes confer neuroprotection by removing excessive extracellular glutamate, potassium, and calcium, while they produce cytokines and chemokines that could be harmful to neurons, if chronically released [18, 23].

Reactive astrocytes effectively engulf dead cells and damaged synapses and protein aggregates [24-31]. Interestingly, astrocytes have been shown to be more efficient than microglia in taking up $A \beta$, particularly during the early stages of $\mathrm{AD}$ [32]. The fact that reactive astrocytes with high $A \beta$ load are frequently found in the human $\mathrm{AD}$ brain, further confirms the importance of astrocytes in $A \beta$ clearance [33]. Yet, the therapeutic potential of astrocytes remains to be investigated. In a recent study, we demonstrated that astrocytes engulf large amounts of $A \beta_{42}$ protofibrils that are accumulated rather than digested by the cells. This intracellular storage of $A \beta$ results in severe astrocytic endosomal/lysosomal defects and secretion of extracellular vesicles with neurotoxic content [31].

The aim of the present study was to investigate if degradation of $A \beta_{42}$ protofibrils by astrocytes can be enhanced by treatment with the $A \beta$ protofibril selective antibody mAb158. Our results demonstrate that the antibody substantially increases clearance of pathological $\mathrm{A} \beta$ by astrocytes and rescues neurons from $A \beta$-induced cell death. This is important data, highlighting a possible role for astrocytes in the cellular response to $A \beta$ immunotherapy.

\section{Methods}

\section{Synthetic $A \beta_{42}$ protofibrils}

Synthetic $A \beta_{42}$ protofibrils used in this study were prepared according to a well-established protocol [15, 31, 34, 35]. Synthetic $A \beta_{42}$ peptides (American Peptide Company Inc.) dissolved in $10 \mathrm{mM} \mathrm{NaOH}$ were neutralized with 10x phosphate-buffered saline (PBS) to $443 \mu \mathrm{M}(2 \mathrm{mg} / \mathrm{ml})$ and incubated $30 \mathrm{~min}$ at $37{ }^{\circ} \mathrm{C}$. Fluorescent HiLyte ${ }^{\mathrm{Tw}}$ Fluor 555-labeled $\mathrm{A} \beta_{42}\left(\mathrm{~A} \beta_{42}-555\right)$ peptides (Anaspec Inc) were diluted in $10 \times \mathrm{PBS}$ to a concentration of $36 \mu \mathrm{M}$, followed by incubation for $4 \mathrm{~h}$ at $37{ }^{\circ} \mathrm{C}$. Both unlabeled $A \beta_{42}$ protofibrils and $A \beta_{42}-555$ protofibrils were centrifuged for $5 \mathrm{~min}$ at $17900 \times g$ to remove any insoluble aggregates. The purity $(>95 \%)$ of the $A \beta_{42}$ protofibril preparation was analyzed by HPLCSEC, using a Superdex 75 column. The SEC chromatogram for the specific batch of protofibrils used in this study is included in our previous paper [31].

\section{Animals}

All experiments involving animals were performed at Uppsala University, Sweden. The experiments were approved by the Uppsala County Animal Ethics Board (ethical permit number: C75/13, valid 2013-06-28 to 2018-0628), following the rules and regulations of the Swedish Animal Welfare Agency, in compliance with the European Communities Council Directive of 22 September 2010 (2010/63/EU). The mice were housed at the animal facility at Uppsala University Hospital, Uppsala, in a 12-12 darklight cycle. The mice were kept in an enriched environment and given water and food ad libitum.

\section{Co-cultures of neurons and glia}

Cerebral cortices from C57/BL6 mice of embryonal day 14 (E14) were dissected in Hank's buffered salt solution supplemented with $50 \mathrm{U} / \mathrm{ml}$ penicillin, $50 \mathrm{mg} / \mathrm{ml}$ streptomycin, and $8 \mathrm{mM}$ Hepes buffer (HBSS, all from Invitrogen). The cortices were dissociated in fresh HBSS, centrifuged at $150 \times g$ and resuspended in cell culture medium. The cells were expanded in DMEM/F12-GlutaMAX supplemented with $1 \times$ B27 supplement, $50 \mathrm{U} / \mathrm{ml}$ penicillin, $50 \mathrm{mg} / \mathrm{ml}$ streptomycin, and $8 \mathrm{mM}$ Hepes buffer, $10 \mathrm{ng} / \mathrm{ml}$ bFGF (all from ThermoFisher) and $20 \mathrm{mg} / \mathrm{ml}$ EGF (VWR). Neurospheres were passaged every second or third day by dissociation in HBSS and resuspended in medium with bFGF and EGF. Prior to experiments, the cells were plated as a monolayer, at a concentration of $1.5 \times 10^{5}$ cells $/ \mathrm{ml}$, on coverslips (In Vitro Diagnostics) or cell culture dishes (Falcon), coated with Poly-L-Ornithine (Sigma-Aldrich) and Laminin 
(Invitrogen). After $24 \mathrm{~h}$, the medium was replaced with mitogen-free medium to initiate cell differentiation to a mixed population of neurons, astrocytes, and oligodendrocytes. Neural stem cells have the capacity to differentiate to neurons, astrocytes, and oligodendrocytes, but not microglia [36-38]. To verify that no microglia were present in the cultures, we performed immunocytochemistry with a specific antibody to Iba-1 (Additional file 1). A brain tissue section from a 16-monthold $\mathrm{APP}_{\text {Arcswe }}$ mouse was included as a positive control. During the 7-day differentiation period, the cell culture medium was changed every second or third day. Only neurospheres from passage 2-4 were used for experiments. Cells were kept at $37{ }^{\circ} \mathrm{C}$ in $5 \% \mathrm{CO}_{2}$ atmosphere.

\section{Antibody fragmentation}

Recombinant mAb158 (RmAb158) was cleaved by the FragIT kit (Genovis AB) according to manufacturer's guidelines to generate $\mathrm{F}\left(\mathrm{ab}^{\prime}\right)_{2}-\mathrm{RmAb} 158$, as previously described [39]. The kit produces a homogenous preparation of $\left.\mathrm{F}(\mathrm{ab})_{2}\right)_{2}$ fragments by using the bacterial enzyme FabRICATOR (IdeS), cleaving IgG at a specific site just below the hinge region. Fc fragments and non-cleaved antibody were removed from the $\left.\mathrm{F}(\mathrm{ab})_{2}\right)_{2}$ fragments with a CaptureSelect Fc affinity resin (ThermoFisher). The products were analyzed by SDS-PAGE under nonreducing conditions to confirm appropriate cleavage (size) and purity of the fragments. Briefly, samples were mixed with Laemmli buffer, loaded onto a NuPage BisTris $4-12 \%$ gel (ThermoFisher) and run at $200 \mathrm{~V}$ for $22 \mathrm{~min}$. The gel was stained with Page Blue (Fermentas) for $1 \mathrm{~h}$ followed by extensive washes in milli- $\mathrm{Q}$ water.

\section{$A \beta$ stimulation and antibody treatment}

Co-cultures of neurons and glia were exposed to $0.1 \mu \mathrm{M}$ $\mathrm{A} \beta_{42}$ protofibrils (either 555-labeled or unlabeled) for $24 \mathrm{~h}$. Controls received fresh cell culture medium without $\mathrm{A} \beta_{42}$ protofibrils. For the antibody treatment, 0 . $1 \mu \mathrm{M} \mathrm{A} \beta_{42}$ protofibrils were incubated for $5 \mathrm{~min}$ with $13 \mathrm{nM}$ of the hybridoma-produced murine mAb158 $\left(\operatorname{IgG}_{2 \mathrm{a}}\right)$ or the recombinantly produced mAb158, RmAb158 $\left(\operatorname{IgG}_{2 \mathrm{c}}\right)$, with or without the N297D mutation (all from BioArctic $\mathrm{AB}$ ), before being added to the cultures. As negative control antibodies, the irrelevant antibody Ly128 ( $\operatorname{IgG}_{1}$, Mabtech), recognizing flagellin in bacteria, and MOPC-173 (IgG Ia $_{2}$ BD Pharmingen), with unknown specificity, were used. It has been proven that Ly-128 does not cross-react with $A \beta$ [16]. For analysis of the $A \beta_{42}$ concentration in media, a lower concentration $\left(0.01 \mu \mathrm{M} \mathrm{A} \beta_{42}\right.$ protofibrils) and reduced volume (400 $\left.\mu \mathrm{l}\right)$ of the cell culture media were added to the co-cultures. The $A \beta_{42}$ protofibrils/A $\beta_{42}-555$ protofibrils and the various antibodies were added to the co-cultures in a volume of $2 \mathrm{ml}$ per well, except when analyzing medium concentrations of $\mathrm{A} \beta$ (then $400 \mu \mathrm{l}$ were used). Following 24-h treatment, the co-cultures were washed in cell culture media three times and the cell-containing coverslips were transferred to new culture dishes. The cells were fixed $(24 \mathrm{~h})$, lysed $(24 \mathrm{~h})$, or cultured for additional 6 ( $24 \mathrm{~h}+6$ days) or 12 days $(24 \mathrm{~h}+12$ days) in $\mathrm{A} \beta$-free cell culture medium prior to fixation or cell lysis. To analyze the effect of $\mathrm{mAb} 158$ on $A \beta_{42}$ protofibril degradation further, mAb158 was added 3 days after the $24 \mathrm{~h} \mathrm{~A} \beta_{42^{-}}$ 555 protofibril exposure before cultured for additional 6 ( $24 \mathrm{~h}+6$ days) or 12 days $(24 \mathrm{~h}+12$ days) and washed thoroughly in $A \beta$-free cell culture medium prior to fixation. Further, in another control experiment, cocultures were incubated with mAb158 for $1 \mathrm{~h}$ and then extensively washed in cell culture media, prior to $24 \mathrm{~h}$ $A \beta_{42}$ protofibril exposure.

\section{Lysosomal and proteosomal inhibition}

In order to investigate the influence of the proteosomal and endosomal-lysosomal pathway on mAb158mediated $A \beta$ reduction in astrocytes, we preincubated co-cultures with the proteosomal inhibitor mg-132 (Calbiochem, Millipore, $10 \mu \mathrm{M}$ ) or the lysosomal inhibitor Bafilomycin (Calbiochem, Millipore, $200 \mathrm{nM}$ ) for $30 \mathrm{~min}$ prior to $A \beta_{42}$ protofibril exposure \pm mAb158 treatment. The inhibitors remained in the media during the 24-h exposure. Following fixation, the accumulation of $A \beta$ was assessed by immuno-fluorescence. The inhibitors did not have any apparent toxic effects in the concentration and exposure times used.

\section{Immunostaining of cell cultures}

Coverslips were fixed for $15 \mathrm{~min}$ in RT with 4\% paraformaldehyde and permeabilized and blocked with $0.1 \%$ Triton X-100 (both from Sigma-Aldrich) and 5\% normal goat serum (NGS, Bionordika) in PBS for $30 \mathrm{~min}$ at RT. Primary antibodies were incubated in $0.1 \%$ Triton X-100 with $0.5 \%$ NGS for $1-4 \mathrm{~h}$ at $\mathrm{RT}$ or $\mathrm{O} / \mathrm{N}$ at $4{ }^{\circ} \mathrm{C}$. Thereafter, the coverslips were thoroughly washed in PBS three times between each step. Incubation with secondary antibodies was performed in $0.1 \%$ Triton X-100 and $0.5 \%$ NGS for $45 \mathrm{~min}$ at $37{ }^{\circ} \mathrm{C}$. The following primary antibodies were used in the study: rabbit anti-glial fibrillary acidic protein (GFAP, 1:400, DakoCytomation), mouse anti-GFAP (1:400, Sigma-Aldrich), mouse antiBIII-tubulin (1:200, Covance), rabbit anti-Iba-1 (1:200, Abcam), polyclonal rabbit anti-A $\beta_{42}$ (1:200, Invitrogen), and monoclonal mouse anti-A $\beta$ antibody $6 \mathrm{E} 10(10 \mu \mathrm{g} /$ $\mathrm{ml}$, epitope: $3-8$, Covance). Secondary antibodies used were AlexaFluor 488 and 555, all against mouse or rabbit (1:200, Molecular probes), and AlexaFlour 488, anti-IgG $\mathrm{I}_{2 \mathrm{a}}$ antibody against mouse (1:200, Life Technologies). Phalloidin-Fluorescein $(2 \mu \mathrm{M}$, Sigma-Aldrich) was used for actin visualization. The coverslips were 
mounted on microscope glass slides using Vectashield hard-set mounting medium with 4',6-diamidino-2-phenylindole (DAPI, DAKO). A Zeiss Observer Z1 Microscope and Carl Zeiss LSM700 confocal microscope (Zeiss) were used for analysis. Images and confocal zstacks were visualized with Zen 2012 software.

\section{Immunostaining of tissue sections}

The analysis of Iba-1 included immunohistochemistry of tissue sections from a 16-month-old $\mathrm{APP}_{\text {ArcSwe }}$ mouse, as a positive control. In short, cryostat brain sections, prepared as previously described [40], were rehydrated in PBS and permeabilized and blocked with $0.3 \%$ Triton X-100 (Sigma-Aldrich) and 5\% NGS (Bionordika) in PBS for $1 \mathrm{~h}$ at RT. The sections were incubated with the primary antibody (rabbit anti-Iba-1, 1:200, Abcam) in 0.5\% NGS in PBS $\mathrm{O} / \mathrm{N}$ at $4{ }^{\circ} \mathrm{C}$. Sections were washed three times for $5 \mathrm{~min}$ in PBS. Incubation with secondary antibody (anti-rabbit Alexa Fluor 488, 1:200, Invitrogen) was performed in $0.5 \%$ NGS in PBS for $1 \mathrm{~h}$ at $37^{\circ} \mathrm{C}$, followed by three washes for $5 \mathrm{~min}$ in PBS. Sections were mounted onto microscope glass slides (Menzel Gläser) using EverBrite mounting medium containing DAPI (Biotium).

\section{Time-lapse experiments}

Time-lapse experiments were performed at $37{ }^{\circ} \mathrm{C}$ in humidified 5\% $\mathrm{CO}_{2}$ atmosphere, using a Nikon Biostation IM Live Cell Recorder (Nikon). The cells were cultured at a concentration of $1.5 \times 10^{5} \mathrm{cells} / \mathrm{ml}$, in time-lapse culture dishes (VWR), and pictures were taken every 10th minute for up to $24 \mathrm{~h}$. A $\beta_{42}-555$ protofibrils and mAb158 labeled with DyLight ${ }^{\text {tw }} 488$ (ThermoFisher) were used in the time-lapse experiments.

\section{Cell medium and lysates}

For $\mathrm{A} \beta$ quantification studies, neurons and glia were cultured at a concentration of $2.4 \times 10^{5}$ cells $/ \mathrm{ml}$ in cell culture dishes (Corning). Following collection of the cell culture medium, the co-cultures were lysed by addition of ice-cold lysis buffer $(20 \mathrm{mM}$ Tris $\mathrm{pH} 7.5,0.5 \%$ Triton X-100, 0.5\% deoxycholic acid, $150 \mathrm{mM} \mathrm{NaCl}, 10 \mathrm{mM}$ EDTA, $30 \mathrm{mM}$ NaPyroP and protease inhibitor (Roche)) to the dish. The lysed cells were collected using a cell lifter (Corning Inc.), transferred to Eppendorf tubes, incubated on ice for $30 \mathrm{~min}$, and centrifuged $\left(30 \mathrm{~min}, 4^{\circ}\right.$ C, $12000 \times g$ ). The medium and cell lysates were stored at $-70{ }^{\circ} \mathrm{C}$ until the time of analysis by ELISA or Western blot.

\section{$A \beta_{1-x}$ and $A \beta_{x-42}$ ELISAs}

For $A \beta_{1-x}$ ELISA, 96 well EIA/RIA plates (Corning Inc.) were coated $\mathrm{O} / \mathrm{N}$ at $4{ }^{\circ} \mathrm{C}$ with the $\mathrm{N}$-terminus specific (epitope 1-5) antibody mAb82E1 (100 ng/well, IBL-
Hamburg) in PBS. Plates were blocked with $1 \%$ bovine serum albumin (BSA) in PBS for $2 \mathrm{~h}$ at RT. Standard series of synthetic $A \beta_{42}$ monomers (American Peptide) and samples were denatured by boiling for $5 \mathrm{~min}$ in 0 . $5 \%$ sodium dodecyl sulfate (SDS) to avoid impaired detection caused by aggregated A $\beta$ [41]. All SDS-treated samples were diluted x10 to decrease the SDS concentration and avoid SDS interference in the ELISAs. Washing was performed by adding $250 \mu \mathrm{l}$ washing buffer (phosphate-buffered $\mathrm{NaCl}$ with $0.1 \%$ Tween-20 and 0 . $15 \%$ Kathon) times three repetitions between each step of the ELISA. All dilutions occurred in ELISA incubation buffer $(0.05 \%$ Tween, $0.1 \%$ BSA, and $0.15 \%$ Kathon in $\mathrm{PBS}$ at $\mathrm{pH}$ 7.4). Plates were incubated for $2 \mathrm{~h}$ before adding biotinylated $4 \mathrm{G} 8(0.3 \mu \mathrm{g} / \mathrm{ml}$, Covance), specific to the mid-region of $A \beta$, as secondary antibody for $1 \mathrm{~h}$. Thereafter, plates were incubated with streptavidin coupled HRP (1:2000, Mabtech AB) for $1 \mathrm{~h}$. K-blue enhanced (Neogen Corporation) was used as HRP substrate, and the reaction was stopped with $1 \mathrm{M} \mathrm{H}_{2} \mathrm{SO}_{4}$. Plates were measured by Tecan Infinite M200 PRO spectrophotometer (Tecan Group Ltd.) at $450 \mathrm{~nm}$ and analyzed with Magellan v7.0 software (Tecan Group Ltd.). For the $A \beta_{x-42}$ ELISA, polyclonal $A \beta_{42}$ antibody (100 ng/well, Agrisera) and biotinylated 4G8 $(0.5 \mu \mathrm{g} / \mathrm{ml})$ were used as primary and secondary antibody, respectively. $A \beta_{x-42}$ ELISA was performed according to the same protocol as the $A \beta_{1-x}$ ELISA, except for prolonged incubation times for blocking, sample $\left(\mathrm{O} / \mathrm{N}, 4{ }^{\circ} \mathrm{C}\right)$ and secondary antibody ( $2 \mathrm{~h}, \mathrm{RT})$ and increased SA-HRP dilution (1:5000).

\section{Western blot analysis}

Medium from the co-cultures was mixed with NuPage sample buffer and NuPage reducing agent (both from ThermoFisher) and incubated for $5 \mathrm{~min}$ at $95{ }^{\circ} \mathrm{C}$. Chameleon duo marker (Li-Cor) was used as a ladder, and medium was loaded according to maximal volume (30 $\mu \mathrm{l} /$ well) on a NuPage Bis-Tris $4-12 \%$ gel (ThermoFisher) and run at $200 \mathrm{~V}$ for $30 \mathrm{~min}$ in MES SDS running buffer (ThermoFisher), followed by transfer to nitrocellulose membrane (Bio-Rad) at $25 \mathrm{~V}$ for $7 \mathrm{~min}$ using a Trans-Blot Turbo system (Bio-Rad). The membrane was briefly washed in Tris-buffered saline (TBS) and blocked in 5\% nonfat dry milk in $0.1 \%$ TBS-Tween for $1 \mathrm{~h}$ at RT, before the primary antibody (polyclonal rabbit anti-A $\beta_{42}, 1: 2000$, Invitrogen) was added and incubated $\mathrm{O} / \mathrm{N}$ at $\mathrm{RT}$ on shaking. The membrane was washed in $0.1 \%$ TBS-Tween for $2 \times 5 \mathrm{~min}$ and $2 \times$ $10 \mathrm{~min}$ prior to $1 \mathrm{~h}$ incubation with secondary antirabbit antibody conjugated with horseradish peroxidase (Pierce) in 0.1\% TBS-Tween. The enhanced chemiluminescence (ECL) system (SuperSignal West Dura Extended Duration Substrate, ThermoFisher) was used for 
development and imaging, and analysis of bands was performed using an ImageQuant 400 GE Odyssey (LiCor). The membrane was re-probed with secondary anti-mouse antibody. Briefly, the membrane was blocked in Odyssey blocking buffer (TBS) (Li-Cor) for $1 \mathrm{~h}$ at RT and incubated with DyLight 800 secondary anti-mouse antibody (1:20000, Invitrogen) in Odyssey blocking buffer (TBS) and 0.1\% TBS-Tween (1:1) for $1 \mathrm{~h}$ at RT. Three washes in $0.1 \%$ TBS-Tween and one wash in TBS followed, before the signal was detected using the Odyssey Sa Imaging system (Li-Cor).

\section{Area and intensity measures of $A \beta$ inclusions and cell counting}

For intensity and area measurements of $A \beta-555,30 \mathrm{im}$ ages (ten images/coverslip from three independent cell cultures) were captured with an $\times 40$ objective on a Zeiss Observer Z1, using the same settings. The images were analyzed with the Zen 2012 software (Zeiss), and all area and intensity measurements were set manually. For analysis of neuronal survival, 30 images (ten images/coverslip from three independent cell cultures) were captured with an $\times 20$ objective on a Zeiss Observer Z1. The number of viable, $\beta I I I-t u b u l i n$ positive neurons was manually quantified in each field. All images were analyzed in a blinded fashion.

\section{Statistics}

All experiments were performed in triplicates with independent co-cultures derived from embryos of different pregnant mice. The results are presented in scatter plots or box plots with mean \pm standard deviation. Since the data were found not to meet the assumption of normal distribution using the Shapiro-Wilk's $W$ test, Kruskal-Wallis ANOVA was used and was followed by Mann-Whitney $U$ test for pairwise comparisons. Western blot intensity measurements were statistically analyzed using one-way ANOVA followed by Tukey's multiple comparison test. Level of significance were set to ${ }^{*} P<0.05$, ${ }^{* *} P<0.01$, and ${ }^{* * * *} P<0.001$.

\section{Results}

The $A \beta$ protofibril selective antibody $\mathrm{mAb} 158$ prevents $A \beta$ accumulation in astrocytes

To investigate if the $A \beta$ protofibril selective antibody, mAb158, could increase $A \beta$ clearance in astrocytes, primary cortical co-cultures containing neurons and glia were exposed to $A \beta_{42}-555$ protofibrils or $A \beta_{42}-555$ protofibrils + mAb158 for $24 \mathrm{~h}$. The cell cultures were either fixed directly after exposure $(24 \mathrm{~h})$ or washed and cultured for an additional 6 (24 h +6 days) or $12(24 \mathrm{~h}+$ 12 days) days without treatment, prior to fixation. Immunocytochemistry against the astrocytic marker GFAP demonstrated that in co-cultures exposed to $A \beta_{42}-555$ protofibrils, the astrocytes contained very large $A \beta$ inclusions, as previously reported [31] (Fig. 1a). Preincubation of the $A \beta_{42}-555$ protofibrils with mAb158 resulted in a dramatic reduction of the astrocytic $A \beta$ inclusions, already at the first time point (Fig. 1b). To investigate if the $A \beta$ protofibril selective antibody mAb158 could affect $A \beta$ accumulation in astrocytes after the $A \beta$ ingestion had taken place, cells were treated with mAb158 3 days after the $24 \mathrm{~h} \mathrm{~A} \beta_{42}-555$ protofibril exposure (mAb158 +3 days). There was no evident effect on $\mathrm{A} \beta$ accumulation in mAb158 + 3-day-treated cocultures compared to co-cultures exposed to $A \beta_{42}-555$ protofibril exposure only (Fig. 1c). In addition, mAb158 added to co-cultures $1 \mathrm{~h}$ prior to the $A \beta_{42}$ protofibril exposure had a reduced effect on astrocytic $A \beta$ accumulation compared to mAb158 co-incubated with $A \beta_{42}$ protofibrils (Additional file 2).

The total 555-intensity, normalized to the number of live cells (Fig. 1d), the number of inclusions (Fig. 1e), and the total area (Fig. 1f) of the intracellular A $\beta-555$ inclusions in the co-cultures were measured using the Zen 2012 software. The quantifications demonstrated that there was a significant reduction in 555-intensity and 555-stained area of the $A \beta$ inclusions at $24 h+6$ days and $24 h+12$ days, when the antibody was present simultaneously with the $\mathrm{A} \beta_{42}-555$ protofibrils $(P<0.001$ for 555 -intensity/number of living cells, 555-intensity/number of $A \beta$ inclusions and area of $A \beta$ inclusions). When the mAb158 antibody was added 3 days after the $A \beta_{42}-555$ protofibril exposure there was no difference in 555-intensity/number of living cells, 555-intensity/number of $A \beta$ inclusions and area of $A \beta$ inclusions as compared to co-cultures exposed to $A \beta_{42}-555$ protofibrils only (Fig. 1d-f). Similar to mAb158, the presence of mAb1C3 (binding pan-A $\beta$ ) [42, 43] lowered the 555 -intensity and 555-stained area of $A \beta$ inclusions in the astrocytes, compared to $A \beta_{42}$ protofibril-exposed astrocytes (Additional file 3 ). This result was expected since mAb1C3 binds to all forms of $A \beta$, including $A \beta_{42}$ protofibrils. To investigate if the effect was specific for $A \beta$ antibodies, cocultures were exposed with $A \beta_{42}$ protofibrils together with the irrelevant antibody $\mathrm{Ly}-128\left(\mathrm{IgG}_{1}\right)$ or $\mathrm{A} \beta_{42}$ protofibrils together with the irrelevant antibody MOPC-173 $\left(\operatorname{IgG}_{2 \mathrm{a}}\right)$. Ly-128 did not reduce the intracellular $A \beta$ accumulation (Additional file 2) and MOPC-173 had a significantly lower effect on the $A \beta$ accumulation, as compared to mAb158 (Additional file 4). In co-cultures treated with the irrelevant antibody MOPC-173, there was a threefold higher 555intensity/live cells, a fivefold higher 555-intensity/number of inclusions, and a threefold larger area/number of 555inclusions, compared to co-cultures treated with mAb158 (Additional file $4 \mathrm{D}$-E). The reason why there was some effect also with the MOPC- 173 antibody is probably that $A \beta$ is a very sticky protein and that the $A \beta_{42}$ protofibrils to some degree bind unspecifically to the MOPC-173 antibody. 


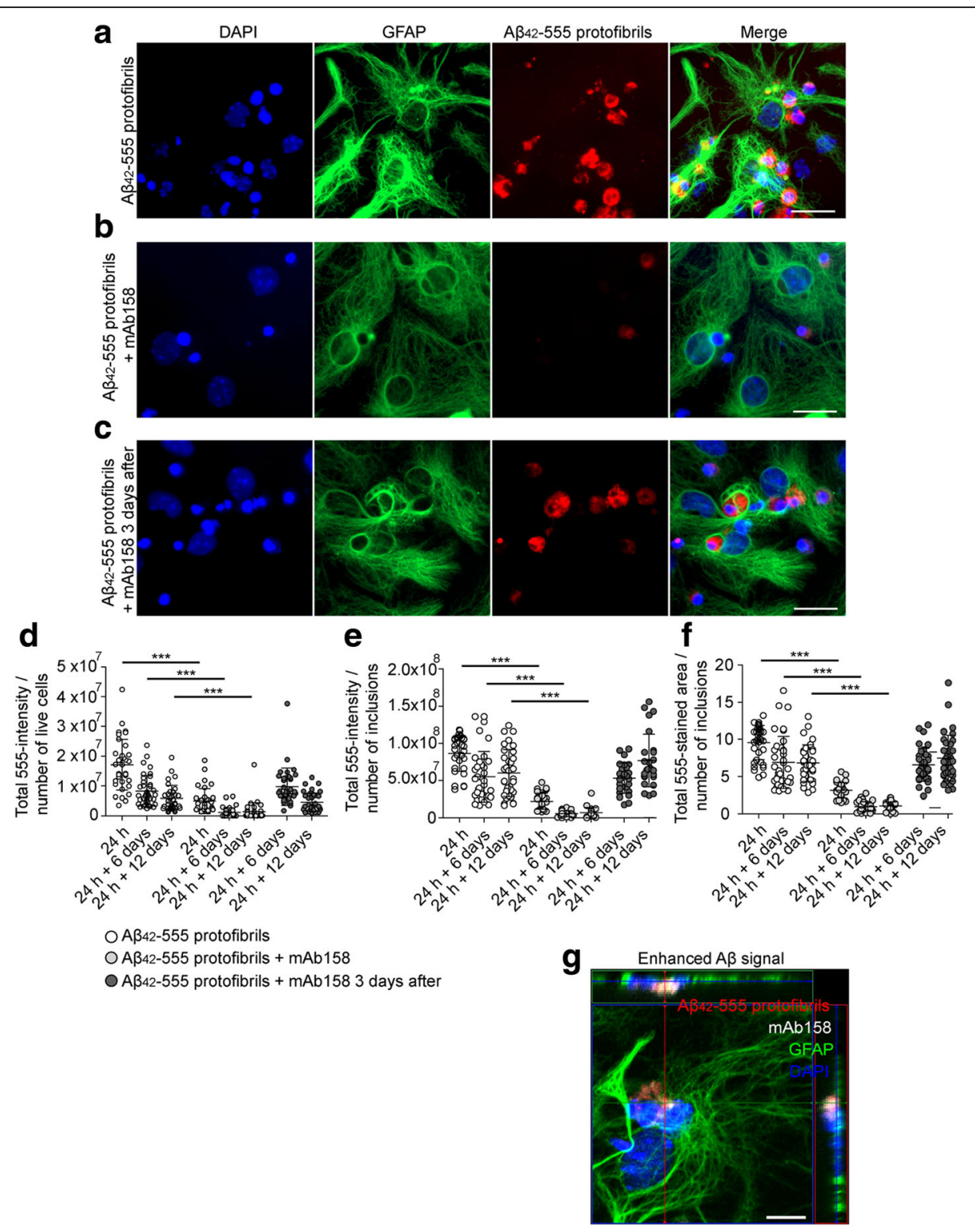

Fig. 1 mAb158 reduces $A \beta$ accumulation in astrocytes. Exposure of co-cultures to $A \beta_{42}-555$ protofibrils for $24 \mathrm{~h}$ results in large $A \beta$ inclusions in astrocytes (a). Concurrent addition of mAb158 clearly reduces the intracellular $A \beta_{42}-555$ in astrocytes (b). However, mAb158 added 3 days after the $A \beta_{42}-555$ protofibril exposure had no effect on $A \beta_{42}-555$ accumulation (c). Using the Zen software, the 555-intensity and 555-stained area of the inclusions were measured. The 555 -intensity/number of living cells (d), 555 -intensity/number of $A \beta$ inclusions (e), and total 555 -stained area of $A \beta-555$ inclusions (f) decreased significantly in co-cultures treated with $A \beta_{42}-555$ protofibrils + mAb158, compared to cultures exposed to $A \beta_{42}-555$ protofibrils only or cultures treated with mAb158 3 days after $A \beta_{42}-555$ protofibril exposure. Confocal imaging demonstrates intracellular co-localization of $A \beta_{42}-555$ protofibrils and mAb158 in astrocyte (g). GFAP (green), DAPI (blue), mAb158 (white), and A $\beta_{42}-555$ (red). The image is an orthogonal view of a confocal z-stack image. The $X Z$ plane and YZ plane are shown at the top and to the right of the XY image, respectively. Scale bar $20 \mu \mathrm{m}$. The experiments were performed in triplicates with independent cell cultures, and 10 images/experiment were analyzed. Statistical analysis using Mann-Whitney $U$ test $\left({ }^{* * *} P<0.001\right)$

mAb158 and $A \beta_{42}$ protofibrils co-localize in astrocytes To be able to follow uptake and accumulation over time, we performed time-lapse experiments of cocultures exposed to $\mathrm{A} \beta_{42}-555$ protofibrils and mAb158 labeled with DyLight ${ }^{\mathrm{m}}$ 488. The recordings of the co-cultures, $30 \mathrm{~min}$ to $24 \mathrm{~h}$ after addition demonstrated that the $\mathrm{A} \beta_{42}-555$ protofibrils and mAb158 were taken up and co-localized inside the astrocytes (identified by their phenotype of an egg "sunny side up", large nuclei, and multi-vesicular cytoplasm). It should be noted that although some $\mathrm{A} \beta_{42}-555$ protofibril uptake was observed, the intracellular accumulation of $\mathrm{A} \beta$ was minute compared to controls that received $A \beta_{42}-555$ protofibrils only (Additional file 5). Confocal microscopy of astrocytes exposed to $A \beta_{42}-555$ protofibrils preincubated with 

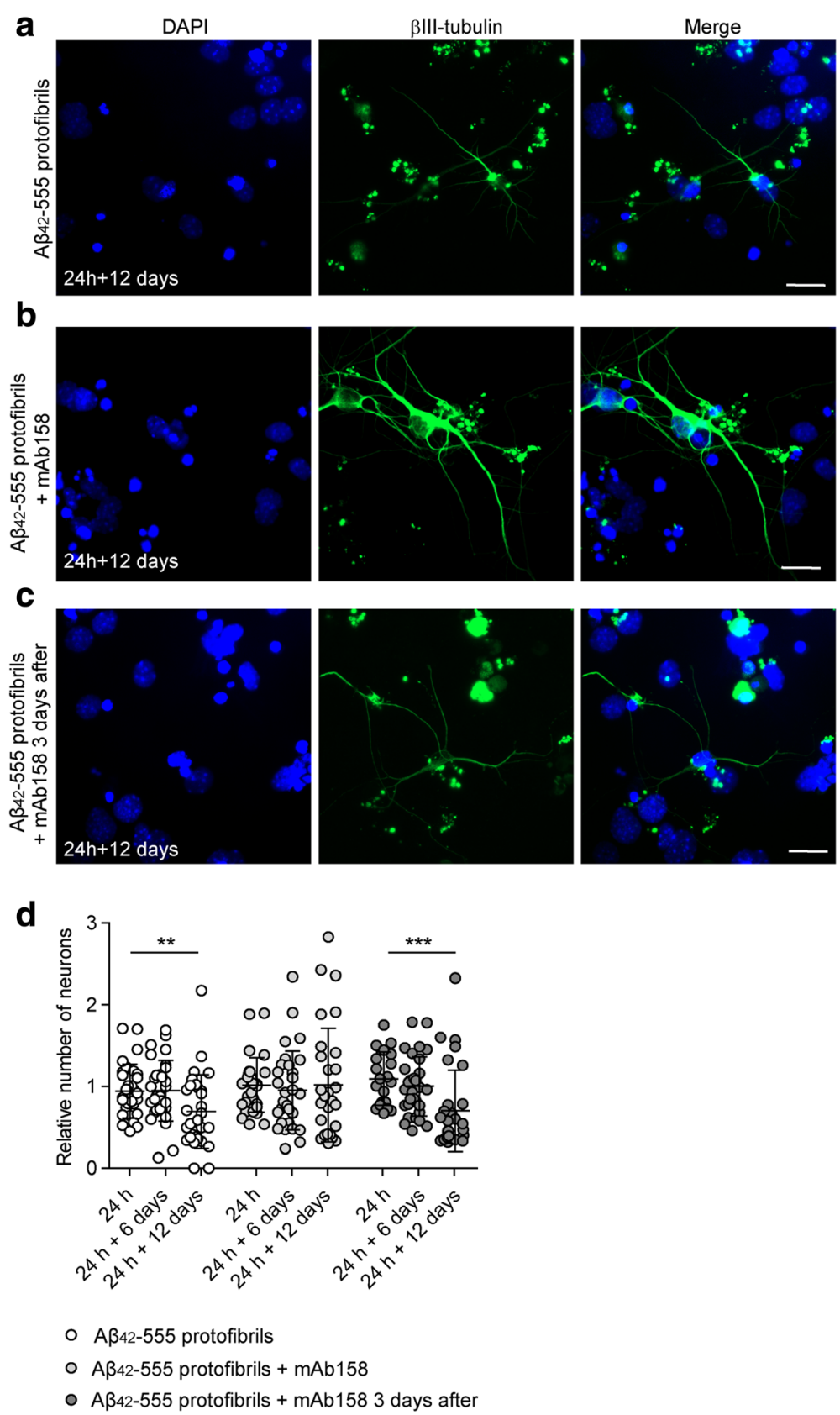

Fig. 2 mAb158 rescues neurons from $A \beta$-induced toxicity. $A \beta_{42}-555$ protofibril exposure of co-cultures results in neuronal cell death 12 days following the removal of the $A \beta_{42}-555$ protofibrils (a). Simultaneous addition of $\mathrm{mAb} 158$, significantly rescued the neurons (b), but this effect was not seen when the mAb158 was added 3 days after the $A \beta_{42}-555$ protofibrils (c). The relative number of living neurons was significantly decreased 12 days following $A \beta_{42}-555$ protofibril exposure $\left(24 h+12\right.$ days, $\left.{ }^{* *} P<0.01\right)$, but no neurotoxic effect was observed at $24 h+12$ days in cultures exposed to $A \beta_{42}-555$ protofibrils together with $m A b 158$. When $m A b 158$ were added 3 days after the $A \beta_{42}-555$ protofibril removal, no protective effect of $m A b 158$ was found ( $\left.{ }^{* * *} P<0.001\right)$ (d). Blll-tubulin (green) and DAPI (blue). Scale bar $20 \mu \mathrm{m}$. The experiments were performed in triplicates with independent cell cultures, and 10 images/experiment were analyzed using Mann-Whitney $U$ test

mAb158 confirmed that low levels of intracellular $A \beta_{42^{-}}$ 555 protofibrils co-localized with mAb158 (Fig. 1g).

\section{mAb158 rescues neurons from $A \beta$-induced toxicity}

We have previously shown that astrocytes exposed to $A \beta_{42}$ protofibrils induce neuronal toxicity by secreting
A $\beta$-containing microvesicles [31]. Hence, we sought to investigate whether mAb158 had any protective effect on $\mathrm{A} \beta_{42}$ protofibril-induced neuronal toxicity in the co-culture system. $A \beta_{42}-555$ protofibrils, preincubated with $\mathrm{mAb158}$, were added to the co-cultures for $24 \mathrm{~h}, 24 \mathrm{~h}+6$, or $24 \mathrm{~h}+$ 12 days. The co-cultures were stained for the neuronal 


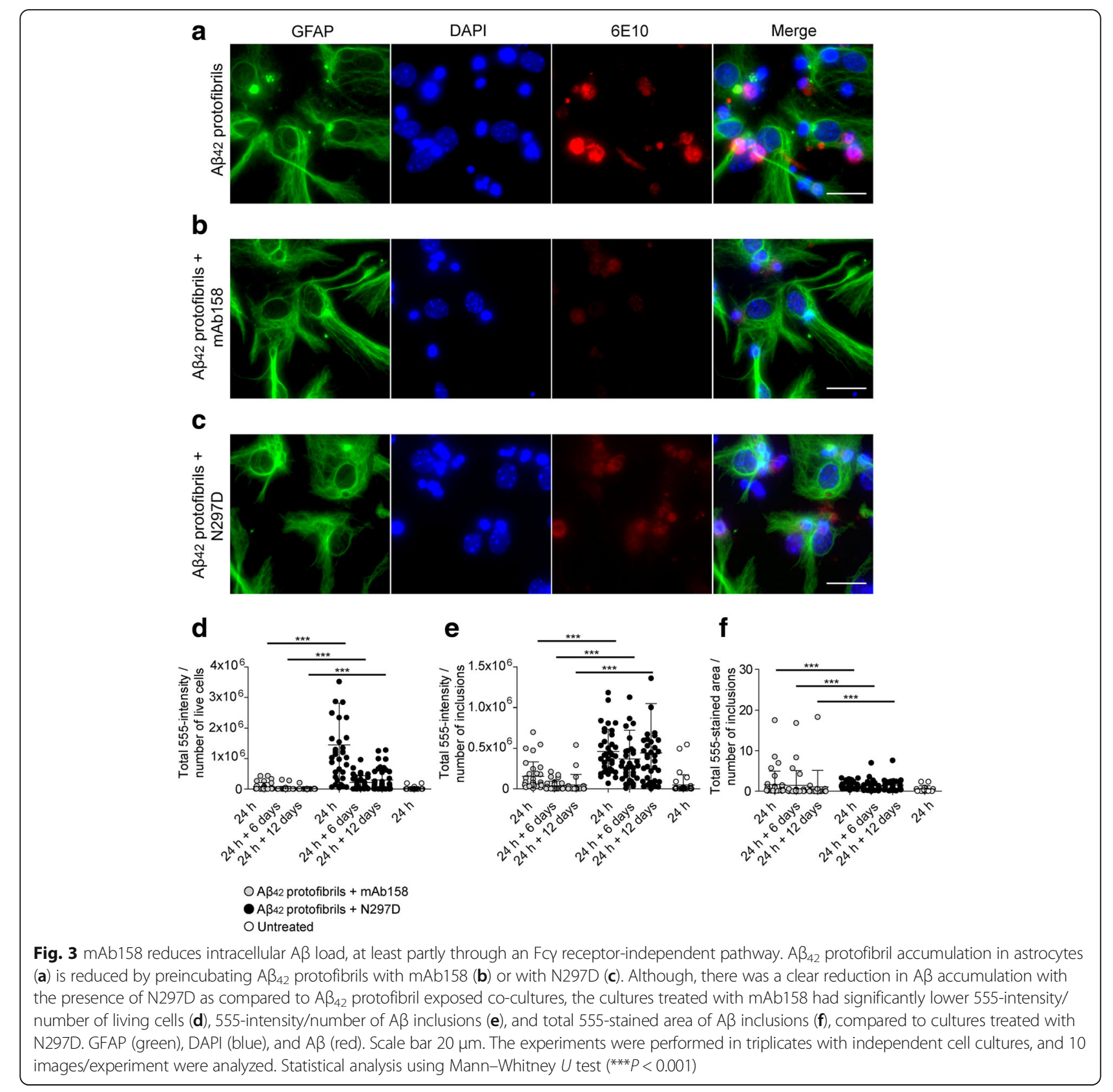

marker BIII-tubulin and for the nuclear dye DAPI, and the number of living neurons was manually counted. As previously shown, $A \beta_{42}-555$ protofibrils significantly decreased the neuronal viability 12 days after $\mathrm{A} \beta_{42}-555$ protofibril removal [31]. Interestingly, the presence of mAb158 rescued neurons from $\mathrm{A} \beta_{42}-555$ protofibril-induced toxicity at $24 \mathrm{~h}+12$ days. However, mAb158 addition 3 days after $A \beta_{42}-555$ protofibril removal had no effect on the viability, and the number of neurons decreased significantly from $24 \mathrm{~h}$ to $24 \mathrm{~h}+$ 12 days $(P<0.0001)$ (Fig. 2$)$.
N297D, a mutated version of RmAb158 with reduced effector function, also lowers $A \beta_{42}$ protofibril, but less effectively

Next, we sought to investigate if the mAb158 effect on $\mathrm{A} \beta_{42}$ protofibril accumulation was $\mathrm{Fc} \gamma$ receptor dependent or independent. For this purpose, we used the N297D antibody, a recombinantly produced mAb158 antibody (RmAb158) with a mutation in the glycosylation site, leading to loss of $\mathrm{F}_{\mathrm{C}} \gamma$ receptor binding and reduced $\mathrm{C} 1 \mathrm{q}$ binding. Both N297D and RmAb158 have the same antigen recognition site as the 

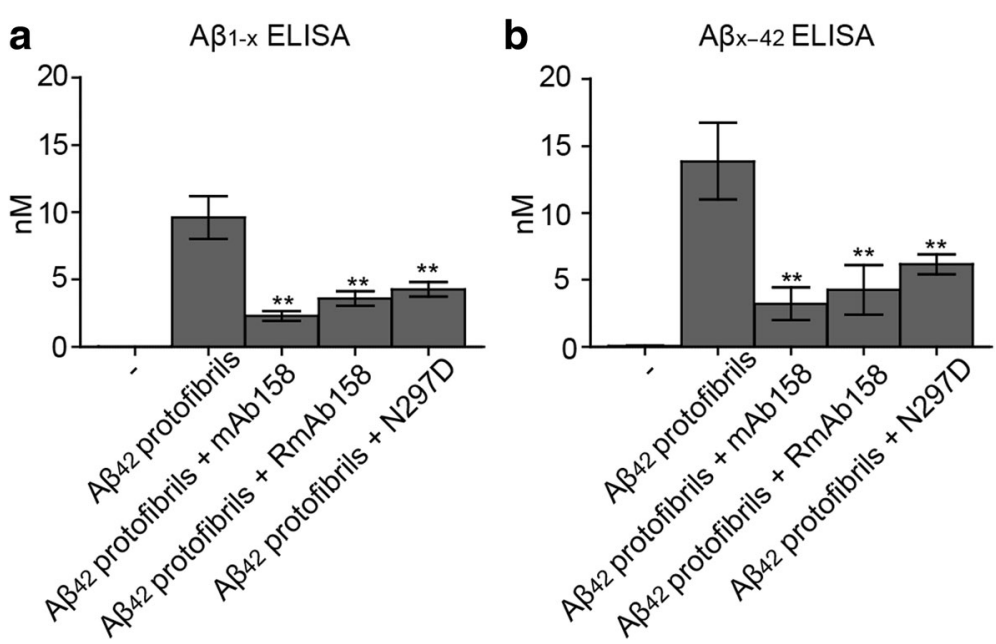

Fig. 4 Anti-A $\beta$ protofibril selective antibodies reduce the levels of intracellular $A \beta$. The $A \beta$ levels in total cell lysates were measured using $A \beta_{1-x}$ and $A \beta_{x-42}$ ELISA. Both $A \beta_{1-x}(\mathbf{a})$ and $A \beta_{x-42}(\mathbf{b})$ levels were reduced in cultures treated with $A \beta_{42}$ protofibrils $+m A b 158, A \beta_{42}$ protofibrils + RmAb158, or $A \beta_{42}$ protofibrils $+N 297 D$, compared to cultures exposed to $A \beta_{42}$ protofibrils only. All concentrations are expressed in nanomolar (nM) units. Mean values are from duplicates of three independent experiments, from two repeated analyses $(* * P<0.01)$

hybridoma-produced mAb158. Immunocytochemistry of fixed co-cultures exposed to $A \beta_{42}$ protofibrils and N297D showed a similar reduction of $A \beta$ accumulation in astrocytes as mAb158 after $24 \mathrm{~h}$ (Fig. 3a-c). The 555intensity and 555-stained area of the intracellular $A \beta$ were measured by the Zen 2012 software. N297D treatment decreased the 555-staining intensity significantly already at $24 \mathrm{~h}$. Although a treatment effect was obtained with N297D, mAb158-treated cultures had significantly lower total 555-intensity per number of living cells and number of the inclusions, and the 555-stained area of the inclusions was significantly smaller (Fig. 3df). As mAb158, RmAb158, a suitable control to N297D, lowered the intracellular $A \beta$ inclusions in astrocytes (Additional file 6). To further study the effect on intracellular $A \beta$ levels in co-cultures exposed to the different treatments, $A \beta_{1-x}$ and $A \beta_{x-42}$ levels were measured by ELISA in cell lysates after $24 \mathrm{~h} \mathrm{~A} \beta_{42}$ protofibril or $A \beta_{42}$ protofibril $+\mathrm{mAb} 158, A \beta_{42}$ protofibril $+\mathrm{RmAb} 158$ or $\mathrm{A} \beta_{42}$ protofibril $+\mathrm{N} 297 \mathrm{D}$ treatment. The levels of $\mathrm{A} \beta_{1-\mathrm{x}}$ $(9614 \pm 3878 \mathrm{pM})$ and $A \beta_{\mathrm{x}-42}(13,845 \pm 2861 \mathrm{pM})$ were markedly reduced upon preincubation of $A \beta_{42}$ protofibrils with mAb158 $\left(\mathrm{A} \beta_{1-\mathrm{x}} 2282 \pm 871 \mathrm{pM}, \mathrm{A} \beta_{\mathrm{x}-42} 3845 \pm\right.$ $1234 \mathrm{pM})$ and RmAb158 $\left(\mathrm{A} \beta_{1-\mathrm{x}} 3577 \pm 1338 \mathrm{pM}, \mathrm{A} \beta_{\mathrm{x}-42}\right.$ $4238 \pm 1851 \mathrm{pM})$. A reduction of $A \beta_{1-\mathrm{x}}$ and $\mathrm{A} \beta_{\mathrm{x}-42}$ levels was also observed for N297D (A $\beta_{1-\mathrm{x}} 4251 \pm 1329 \mathrm{pM}$, $\mathrm{A} \beta_{\mathrm{x}-42} 6153 \pm 739$ pM) (Fig. 4a, b).

To elucidate the extracellular levels of $A \beta_{42}$, we performed Western blot analysis on the cell culture media from nonexposed and $A \beta_{42}$ protofibril-exposed co-cultures with or without co-incubation of mAb158 for $24 \mathrm{~h}$. A reduction of $A \beta_{42}$ was observed in the presence of mAb158, compared to the $A \beta_{42}$ protofibril-exposed co-cultures (Fig. 5a). Detection of low-molecular $\mathrm{A} \beta_{42}$ was found at both $\sim 10 \mathrm{kDa}$ (Fig. $5 \mathrm{~b}$ ) and $\sim 5 \mathrm{kDa}$ (Fig. $5 \mathrm{c}$ ) and a smear of $A \beta_{42}$ was detected from $\sim 38-160 \mathrm{kDa}$ (Fig. $5 \mathrm{~d}$ ). In all three $\mathrm{A} \beta$ fractions, the $\mathrm{A} \beta_{42}$ levels were decreased in mAb158-treated co-cultures. This effect was significant for the $\sim 10 \mathrm{kDa}$ dimer band, which is most likely a result of incomplete SDS-denaturing of the larger $A \beta_{42}$ aggregates that the mAb158 selectively binds to. These results indicate that there is an increased clearance of $\mathrm{A} \beta_{42}$ protofibrils from the cell culture media in the presence of mAb158. The unknown band appearing at $\sim 30 \mathrm{kDa}$ in the cell culture media of mAb158-treated co-cultures could be due to unspecific binding of the primary antibody or cross-reactivity of the mAb158 light chain and the secondary antibody. Blotting the filter with a secondary mouse IgG antibody showed that both the heavy and light chain of the mAb158 antibody can be detected in the media of antibodytreated cultures (Additional file 7). Most likely the mAb158 antibody is bound to $A \beta$ that remains in the media at this time point and has not yet been cleared by the cells.

\section{mAb158 $F\left(a b^{\prime}\right)_{2}$ reduces $A \beta$ accumulation in astrocytes}

To confirm that the effect of mAb158 on $A \beta_{42}$ protofibril degradation was an $\mathrm{Fc} \gamma$ receptor-independent mechanism, the $\mathrm{F}(\mathrm{ab})_{2}$ fragments of $\mathrm{mAb} 158$ were coincubated with $A \beta_{42}$ protofibrils. The $F\left(a b^{\prime}\right)_{2}$ fragment lacks its Fc domain and will therefore not bind to the $\mathrm{Fcy}$ receptor on the cells. Similar to mAb158, cocultures exposed to $F\left(a b^{\prime}\right)_{2} \mathrm{mAb} 158+\mathrm{A} \beta_{42}$ protofibrils for $24 \mathrm{~h}$ reduced the astrocytic accumulation of $A \beta$ (Fig. 6). Taken together, our data indicate that the effect of mAb158 on $A \beta_{42}$ protofibril degradation occurs mainly through Fc $\gamma$ receptor-independent mechanisms. 


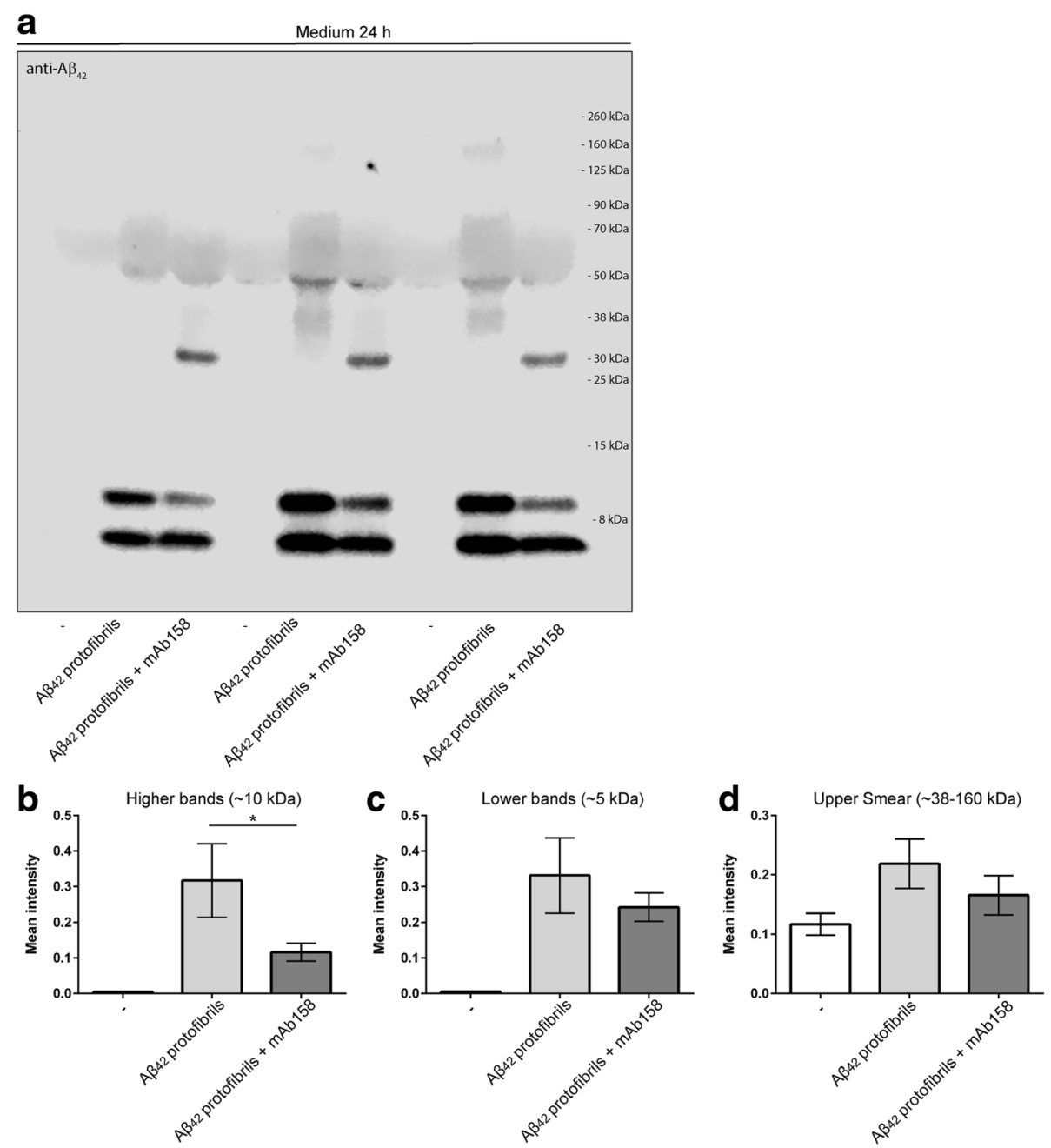

Fig. 5 In the presence of $m A b 158, A \beta$ is cleared from the cell culture media. Western blot analysis showed a reduction of $A \beta$ in the cell culture media of cultures exposed to $A \beta_{42}$ protofibrils + mAb158, compared to cultures exposed to $A \beta_{42}$ protofibril only (a). The reduction was seen both in low-molecular $A \beta$ at $\sim 10 \mathrm{kDa}$ (b) and $\sim 5 \mathrm{kDa}$ (c) and in the smear of $\mathrm{A} \beta$ detected at $\sim 38-160 \mathrm{kDa}$ (d). Intensity measurements were performed from three independent cell culture experiments, and statistical analysis was performed using one-way ANOVA followed by Tukey's multiple comparison test $\left({ }^{*} P<0.05\right)$

\section{Proteosomal or endosomal-lysosomal inhibitors do not alter mAb158-mediated effects}

In order to investigate the influence of the proteosomal and endosomal-lysosomal pathway on mAb158mediated $A \beta$ reduction in astrocytes, we preincubated co-cultures with the proteosomal inhibitor mg-132 or the lysosomal inhibitor bafilomycin for $30 \mathrm{~min}$ prior to $A \beta_{42}$ protofibril exposure \pm mAb158 treatment. The inhibitors were also present during the 24-h exposure. Neither mg-132 nor Bafilomycin had any clear effect on the mAb158-mediated reduction of $\mathrm{A} \beta$ deposits in astrocytes (Fig. $7 \mathrm{a}-\mathrm{d}$ ). Measurement of the 555-intensity/number of living cells (Fig. 7e), 555intensity/number of $A \beta$ inclusions (Fig. 7f), and 555stained area of $A \beta$ inclusions (Fig. $7 \mathrm{~g}$ ) demonstrated that there was a significant reduction in $A \beta$ at all the time points, confirming that the inhibitors did not interfere with the action of mAb158.

\section{Discussion}

Accumulation of $\mathrm{A} \beta$ is a main event in $\mathrm{AD}$ pathology. Since the majority of the patients with sporadic, lateonset, $\mathrm{AD}$ do not have an increased $\mathrm{A} \beta$ production, insufficient lysosomal degradation has been suggested to be the most common cause of the disease for these patients [4446]. Immunotherapy has emerged as a promising method to target $\mathrm{A} \beta$ pathology, and numerous antibodies directed towards different $A \beta$ species are presently evaluated in clinical trials as therapeutics for $\mathrm{AD}$. These antibodies may enhance clearance and/or prevent aggregation of $A \beta$, but the underlying mechanisms and the role of different cell types in A $\beta$-directed immunotherapy are still poorly 


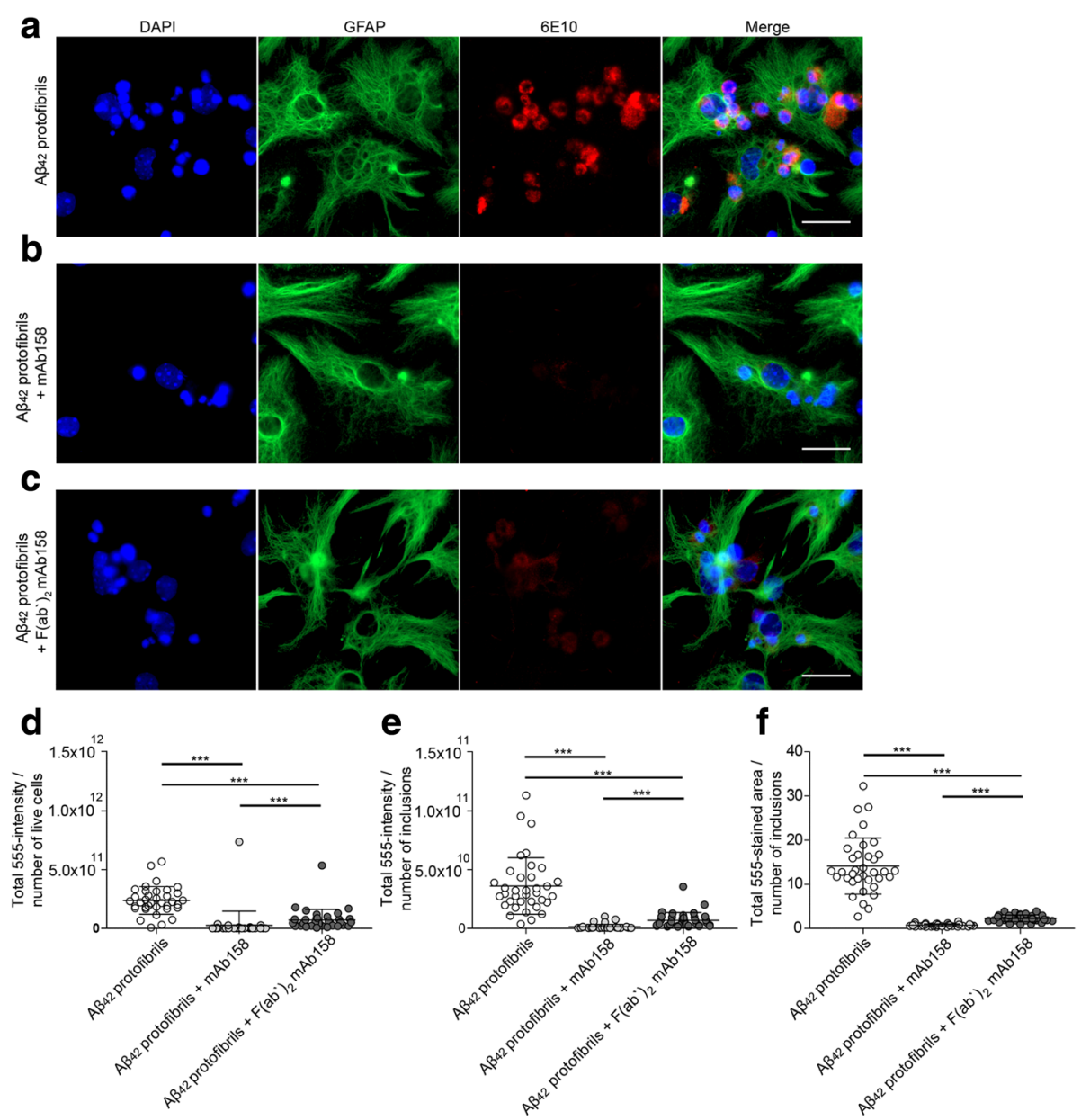

Fig. 6 mAb158 $F\left(a b^{\prime}\right)_{2}$ fragments reduce $A \beta$ accumulation in astrocytes. To confirm that the effect of $m A b 158$ on $A \beta_{42}$ protofibril degradation was a Fcy receptor-independent mechanism, cell cultures were exposed to the $F\left(a b^{\prime}\right)_{2}$ fragments of mAb158 together with the $A \beta_{42}$ protofibrils. Astrocytes in co-cultures exposed to $A \beta_{42}$ protofibrils accumulated $A \beta$ (a) but not when co-treated with mAb158 (b). In cultures treated with $F\left(a b^{\prime}\right)_{2} m A b 158+A \beta_{42}$ protofibrils, the accumulation of $A \beta$ was reduced, almost to the same level as for mAb158 (c). The 555-intensity/number of living cells (d), 555-intensity/number of $A \beta$ inclusions (e), and total 555-stained area of $A \beta$ inclusions (f) were all significantly reduced in co-cultures treated with $A \beta_{42}$ protofibril $+m A b 158$ and $A \beta_{42}$ protofibril $+m A b 158 \mathrm{~F}\left(a b^{\prime}\right)_{2}$ fragments, as compared to $A \beta_{42}$ protofibril exposed co-cultures. GFAP (green), DAPI (blue), and A (red). Scale bar $20 \mu \mathrm{m}$. The experiments were performed in triplicates with independent cell cultures, and 10 images/experiment were analyzed using Mann-Whitney $U$ test $\left.{ }^{* * *} P<0.001\right)$

understood. Here, we demonstrate for the first time that the $A \beta$ protofibril selective monoclonal antibody mAb158 [47] increases clearance of pathological $A \beta$ by astrocytes and thereby rescues neurons from secondary cell death.

Recently, BAN2401 [48], the humanized version of mAb158, was developed in a collaboration between BioArctic $A B$ and Eisai and is currently evaluated in a phase $2 \mathrm{~b}$ clinical trial [49]. Although mAb158 has been shown to reduce brain levels of $A \beta$ protofibrils and prevent $A \beta$ deposition in mouse models of $A D[16,48]$, the cellular mechanism of its action has not been elucidated.

We have previously demonstrated that astrocytes efficiently engulf $A \beta_{42}$ protofibrils, but then store rather than degrade the ingested aggregates [31]. The aim of the present study was to investigate if the astrocytes' potency to clear $A \beta_{42}$ protofibrils could be modulated by the presence of mAb158. Our results demonstrate that mAb158 indeed affects the accumulation of $A \beta$ in astrocytes, but that $A \beta_{42}$ protofibrils and mAb158 need to be administered at the same time to enhance $A \beta_{42}$ protofibril clearance, suggesting that the antibody must form a complex with $A \beta$ to have an effect. Antibodies added to the cultures 3 days after the $A \beta_{42}$ protofibril exposure had no effect on $A \beta$ clearance.

In the presence of $A \beta$ antibodies, phagocytic cells may clear $A \beta$ through $F c \gamma$ receptor-mediated phagocytosis $[50,51]$. The Fc region is highly sensitive to the presence of glycosylation at a single $\mathrm{N}$-linked glycosylation site at asparagine 297 (N297), with a loss of binding to the low-affinity Fcy receptors and diminished activation of 


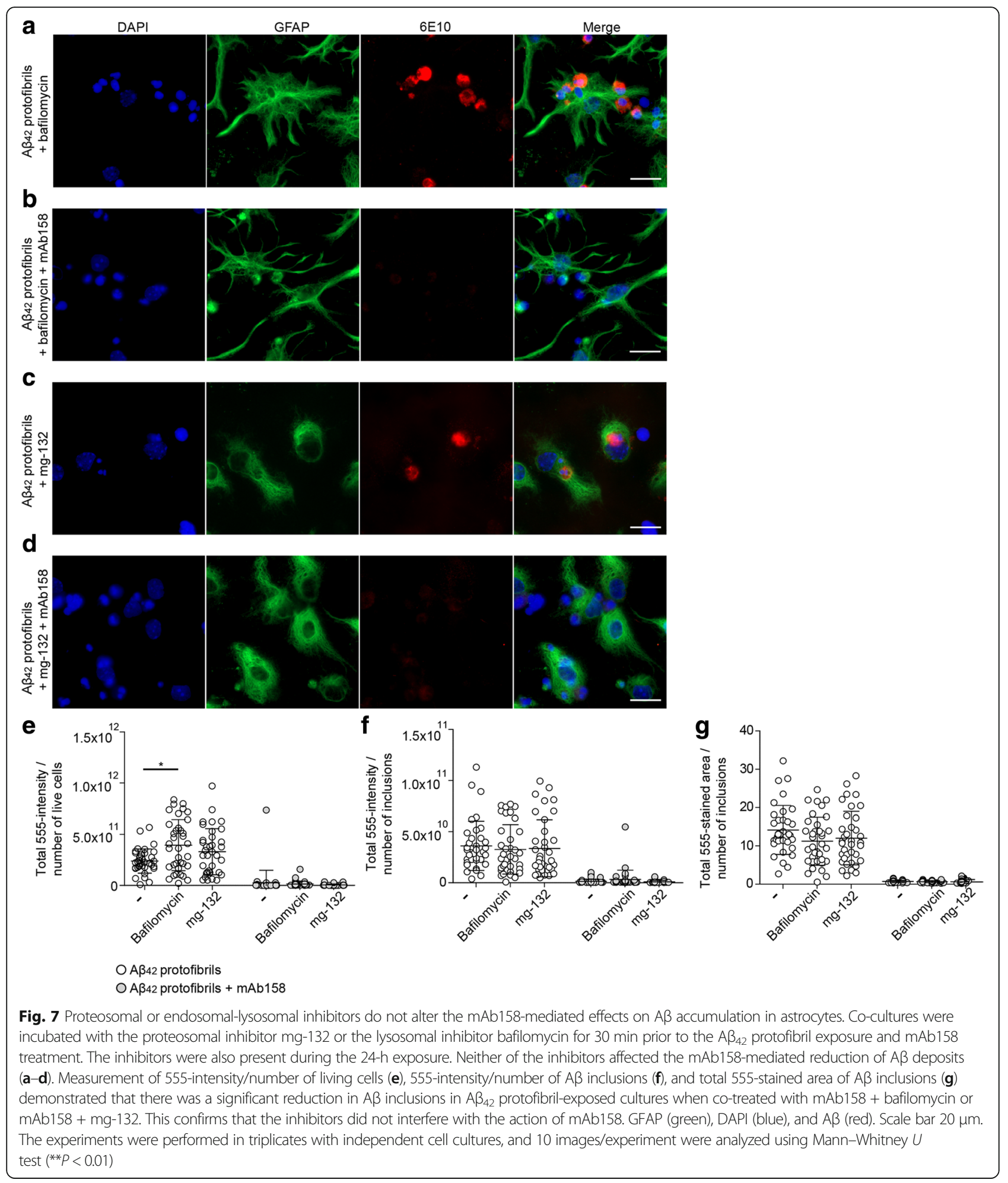

the complement pathway observed in N297 point mutants [52-54]. Interestingly, we found that mAb158 containing a N297D mutation (Asparagine replaced by Aspartic acid) showed almost as good $A \beta$ clearing effect in the astrocytes, as the mAb158 without mutation. To fully elucidate whether the effect of mAb158 on $A \beta_{42}$ protofibril degradation was a $\mathrm{Fc} \gamma$ receptor-dependent or Fcy receptor-independent mechanism, we studied the effect of a $F\left(a b^{\prime}\right)_{2}$ fragment of mAb158. The $F\left(a b^{\prime}\right)_{2}$ fragment lacks its Fc region and can therefore not bind to 
any of the $\mathrm{Fc} \gamma$ receptors. Our data showed $\mathrm{F}\left(\mathrm{ab} \mathrm{b}_{2}\right.$ mAb158 also significantly reduced the accumulation of $\mathrm{A} \beta$ in astrocytes, indicating that the effect of mAb158 on $\mathrm{A} \beta_{42}$ protofibril degradation is mainly a $\mathrm{Fc} \gamma$ receptorindependent mechanism. Our results go well in line with studies performed by Leabman et al. [55], where deglycosylation of antibodies reduced $\mathrm{Fc} \gamma$ receptor binding, but did not affect pharmacokinetics of the antibody compared to the wildtype antibody [56]. Moreover, observations in transgenic $A D$ mice show that $A \beta$ can be cleared through $\mathrm{Fc} \gamma$ receptor-independent mechanisms after treatment with $\left.\mathrm{F}(\mathrm{ab})_{2}\right)_{2}$ fragments lacking the Fc region and after anti-A $\beta$ immunization in $\mathrm{Fc} \gamma$ receptor ${ }^{-/-}$ knockout mice $[57,58]$.

Our results show that inhibition of the lysosomal or proteosomal pathway did not have an impact on the reduced accumulation, possibly indicating that the majority of the $A \beta$ antibody-A $\beta_{42}$ protofibril complexes may be degraded by another, not yet described mechanism. An explanation for the reduced intracellular deposits of $A \beta$ could be a lower uptake or an increased recycling and secretion of the engulfed $A \beta$ antibody- $A \beta_{42}$ protofibril complexes. However, since astrocytes engulf larger particles by macropinocytosis [59], a non-selective engulfment in which the cells take up large gulps of the surrounding liquid (and free-floating particles), the uptake cannot be blocked by the presence of an antibody. Moreover, our ELISA and Western blot analyses of lysates and conditioned media showed that both the intraand extracellular levels of $A \beta$ were lowered in the antibody-treated cultures. In accordance, the time-lapse recordings indicated a treatment-related decrease in the astrocytic accumulation and absence of free-floating $A \beta$ antibody- $A \beta_{42}$ protofibril complexes. The reason why the addition of mAb158 after $\mathrm{A} \beta_{42}$ protofibril exposure (and washes) had no effect, is probably due to the fact that no $A \beta$ remains in the medium, but is situated intracellularly, in endosomal compartments [31] and might not be easily accessible by the antibodies.

\section{Conclusion}

In conclusion, our data demonstrate that the $A \beta$ antibody-A $\beta_{42}$ protofibril complexes do not accumulate in the astrocytes to the same extent as $A \beta_{42}$ protofibrils alone, but are rather cleared from the co-culture. This is in line with our previous data, demonstrating that alphasynuclein selective antibodies promote clearance of both intracellular and extracellular alpha-synuclein aggregates $[59,60]$.We have previously reported that accumulation of $A \beta_{42}$ protofibrils by astrocytes result in increased neurotoxicity, due to secretion of microvesicles containing truncated $A \beta_{42}$ [31]. Interestingly, enhanced $A \beta$ degradation in astrocytes, treated with mAb158, protected neurons from $A \beta_{42}$ protofibril-induced toxicity.
To enable development of new therapeutic targets for $\mathrm{AD}$, increased understanding of the pathways behind engulfment and intracellular degeneration of $A \beta$ is necessary. In order to optimize the design of future $A \beta$ antibodybased therapies, we believe that more studies are needed, focusing on various cell types, including astrocytes.

\section{Additional files}

Additional file 1: Iba-1 immunostaining confirms the absence of microglia in the co-cultures. Immunocytochemistry, with a specific antibody to Iba-1, were performed to verify that no microglia were present in the co-cultures (A). A brain tissue section from a 16-month-old APP $_{\text {ArcSwe }}$ mouse was included as a positive control (B). Microglia were not detected in the co-cultures, but were frequently found in the positive control. Scale bars: $20 \mu \mathrm{m}$. (TIFF $4932 \mathrm{~kb}$ )

Additional file 2: The irrelevant antibody $L y-128$ does not reduce the intracellular $A \beta$ accumulation. The $A \beta$ aggregates that were formed in astrocytes in $A \beta_{42}$ protofibril exposed cultures $(A)$ were clearly reduced in the presence of mAb158 (B). To ensure that this effect was specific for $A \beta$ antibodies, mAb158 was exchanged to the irrelevant antibody Ly-128 $\left(\operatorname{lgG}_{1}\right)(C)$. Ly-128 did not reduce the intracellular $A \beta$ accumulation. In addition, mAb158 had only a minor effect on the $A \beta$ accumulation if it was added to the co-cultures for $1 \mathrm{~h}$ prior to the $A \beta_{42}$ protofibril exposure (D). mAb158 had a significantly higher effect on the $A \beta$ accumulation, compared to mAb158 (1 h). The total 555-intensity was analyzed per number of live cells (E) and number of inclusions (F), and the total 555-stained area per number of inclusions (G) significantly decreased when treated with mAb158 compared to $A \beta_{42}$ protofibril or $A \beta_{42}$ protofibril + Ly-128 exposed co-cultures. GFAP (green), DAPI (blue), $A \beta_{42}$ (red). Scale bar: $20 \mu \mathrm{m}$. The experiments were performed in triplicates with independent cell cultures and 10 images/experiment were analyzed using Mann-Whitney $U$-test $\left({ }^{* *} P<0.01\right.$ and $\left.{ }^{* * *} P<0.001\right)$. (TIFF 5989 kb)

Additional file 3: The mAb1C3 lowers $A \beta$ inclusions in astrocytes. $A \beta_{42}$ protofibrils were accumulated in astrocytes $(A)$, but addition of the mAb1C3, binding pan- $A \beta$, to the co-cultures lowered the accumulation of $A \beta_{42}$ protofibrils (B). The total 555-intensity was analyzed per number of live cells (C) and number of inclusions (D), and the total 555-stained area per number of inclusions (E). Taken together, the analyses confirmed that mAb1C3 lowers $A \beta_{42}$ inclusions in astrocytes. Phalloidin (green), DAPI (blue), $A \beta_{42}$ (red). Scale bar: $20 \mu \mathrm{m}$. The experiments were performed in triplicates with independent cell cultures and 10 images/experiment were analyzed using Mann-Whitney U-test (***P<0.001). (TIFF $6026 \mathrm{~kb}$ )

Additional file 4: The irrelevant antibody MOPC-173 has a significantly lower effect on $A \beta$ accumulation in astrocytes than mAb158. $A \beta_{42}$ protofibrils were accumulated in astrocytes (A), and addition of mAb158 to the co-cultures lowered the accumulation of $A \beta_{42}$ protofibrils (B). Addition of the irrelevant antibody MOPC -173 partly lowered the $A \beta_{42}$ accumulation in astrocytes (C). The total 555-intensity was analyzed per number of live cells (D) and number of inclusions (E), and the total 555-area per number of inclusions (F). Taken together, the analysis shows that mAb158 had a significantly higher effect on the $A \beta$ accumulation, compared to MOPC-173. Phalloidin (green), DAPI (blue), A $\beta_{42}$ (red). Scale bar: $20 \mu \mathrm{m}$. The experiments were performed in triplicates with independent cell cultures and 10 images/experiment were analyzed using Mann-Whitney $U$-test ( ${ }^{*} P<0.01$ and ${ }^{* *} P<0.001$ ). (TIFF $5931 \mathrm{~kb}$ )

Additional file 5: $A \beta_{42}-555$ protofibrils and $\mathrm{mAb} 158$ are engulfed and co-localize inside astrocytes. Time-lapse recording demonstrating co-localization between $A \beta_{42}-555$ protofibrils and DyLight ${ }^{\mathrm{TM}} 488$ labeled mAb158 antibody in astrocytes (A). However, in the presence of antibodies, $A \beta_{42}-555$ protofibrils reached much weaker signals, compared to cultures exposed to $A \beta_{42}-555$ protofibrils only (B). Scale bars: $A$ and $B$ $=10 \mu \mathrm{m}$. (TIFF $6980 \mathrm{~kb}$ )

Additional file 6: $\mathrm{RmAb} 158$ reduces $A \beta$ inclusions in astrocytes. Co-cultures were exposed to $A \beta_{42}$ protofibrils $(A)$ or $A \beta_{42}$ protofibrils 
together with RmAb158 ( $\mathrm{gG}_{2 c}$ (B). Measurements of the total 555 intensity per number of live cells $(C)$ and number of inclusions (D), and the total 555-area per number of inclusions (E) confirmed that RmAb158 reduces $A \beta$ inclusions in astrocytes. GFAP (green), DAPI (blue), A $\beta$ (red). Scale bar: $20 \mu \mathrm{m}$. The experiments were performed in triplicates with independent cell cultures and 10 images/experiment were analyzed using Mann-Whitney U-test (***P<0.001). (TIFF $4151 \mathrm{~kb}$ )

Additional file 7: The heavy and light chain of the mAb158 antibody can be detected in the media. Reprobing the filter in Fig. 5 with a secondary anti-mouse $\lg G$ antibody, showed that both the heavy and light chain of the mAb158 antibody can be detected in the media of antibody-treated cultures. (TIFF $2941 \mathrm{~kb}$ )

\section{Abbreviations}

AD: Alzheimer's disease; $A \beta$ : Amyloid beta; $A \beta_{42}-555$ : Fluorescent HiLyte ${ }^{\mathrm{TM}}$ Fluor 555-labeled A $\beta_{42}$; BSA: Bovine serum albumin; DAPI: 4',6-Diamidino-2phenylindole; E14: Embryonal day 14; ECL: Enhanced chemiluminescence; GFAP: Glial fibrillary acidic protein; N297: N-linked glycosylation site at asparagine 297; NGS : Normal goat serum; PBS: Phosphate-buffered saline; RmAb158: Recombinant mAb158; SDS: Sodium dodecyl sulfate

\section{Acknowledgements}

The authors thank Charlotte Sahlin at BioArctic AB for performing the intensity measurements of the Western blot analysis.

\section{Funding}

This work was supported by grants from the Swedish Research Council (\#2012-2172), the Swedish Alzheimer Foundation, Åhlén Foundation, Stohnes Foundation, Magnus Bergvall Foundation, The Dementia Association Foundation, Hedlund Foundation, and the Uppsala Berzelii Technology Centre for Neurodiagnostics.

\section{Availability of data and materials}

All data generated or analyzed during this study are included in this published article and its supplementary information files.

\section{Authors' contributions}

SS designed and performed the experiments, interpreted the data, and wrote the manuscript; EN performed the experiments, interpreted the data, and wrote the manuscript; LG and MZ performed the experiments and interpreted the data; LS participated in the design of the study and revised the manuscript; DS participated in the design of the study and interpreting the data and revised the manuscript; LL participated in the design of the study and revised the manuscript. AE designed and performed the experiments, interpreted the data, coordinated the study, and wrote the manuscript. All authors read and approved the final manuscript.

\section{Ethics approval and consent to participate}

All experiments involving animals were performed at Uppsala University, Sweden. The experiments were approved by the Uppsala County Animal Ethics Board (ethical permit number: C75/13, valid 2013-06-28 to 2018-06-28), following the rules and regulations of the Swedish Animal Welfare Agency, in compliance with the European Communities Council Directive of $22 \mathrm{Sep}$ tember 2010 (2010/63/EU)

\section{Consent for publication}

Not applicable.

\section{Competing interests}

LS is employed by BioArctic $A B$. $L L$ is a co-founder of BioArctic $A B$ and stock owner. This does not alter to the Journal of Neuroinflammation policies on sharing data and materials. None of the authors have any financial relationship with the organizations that sponsored the research. The other authors declare that they have no competing interests.

\section{Publisher's Note}

Springer Nature remains neutral with regard to jurisdictional claims in published maps and institutional affiliations.

\section{Author details}

Department of Public Health and Caring Sciences, Molecular Geriatrics, Rudbeck Laboratory, Uppsala University, Uppsala, Sweden. ${ }^{2}$ BioArctic AB, Warfvinges väg 35, SE-112 51 Stockholm, Sweden.

\section{Received: 3 January 2018 Accepted: 19 March 2018}

Published online: 28 March 2018

\section{References}

1. Walsh DM, Klyubin I, Fadeeva JV, Cullen WK, Anwyl R, Wolfe MS, Rowan MJ, Selkoe DJ. Naturally secreted oligomers of amyloid beta protein potently inhibit hippocampal long-term potentiation in vivo. Nature. 2002;416:535-9.

2. Lee SJ, Nam E, Lee HJ, Savelieff MG, Lim MH. Towards an understanding of amyloid-beta oligomers: characterization, toxicity mechanisms, and inhibitors. Chem Soc Rev. 2017:46:310-23.

3. Williams TL, Serpell LC. Membrane and surface interactions of Alzheimer's Abeta peptide-insights into the mechanism of cytotoxicity. FEBS J. 2011; 278:3905-17.

4. Klyubin I, Walsh DM, Cullen WK, Fadeeva JV, Anwyl R, Selkoe DJ, Rowan MJ. Soluble Arctic amyloid beta protein inhibits hippocampal long-term potentiation in vivo. Eur J Neurosci. 2004;19:2839-46.

5. Hartley DM, Walsh DM, Ye CP, Diehl T, Vasquez S, Vassilev PM, Teplow DB, Selkoe DJ. Protofibrillar intermediates of amyloid beta-protein induce acute electrophysiological changes and progressive neurotoxicity in cortical neurons. J Neurosci. 1999;19:8876-84.

6. Lacor PN, Buniel MC, Furlow PW, Clemente AS, Velasco PT, Wood M, Viola $\mathrm{KL}$, Klein WL. Abeta oligomer-induced aberrations in synapse composition, shape, and density provide a molecular basis for loss of connectivity in Alzheimer's disease. J Neurosci. 2007;27:796-807.

7. Whalen BM, Selkoe DJ, Hartley DM. Small non-fibrillar assemblies of amyloid beta-protein bearing the Arctic mutation induce rapid neuritic degeneration. Neurobiol Dis. 2005;20:254-66.

8. Shankar GM, Bloodgood BL, Townsend M, Walsh DM, Selkoe DJ, Sabatini BL. Natural oligomers of the Alzheimer amyloid-beta protein induce reversible synapse loss by modulating an NMDA-type glutamate receptor-dependent signaling pathway. J Neurosci. 2007;27:2866-75.

9. Townsend M, Shankar GM, Mehta T, Walsh DM, Selkoe DJ. Effects of secreted oligomers of amyloid beta-protein on hippocampal synaptic plasticity: a potent role for trimers. J Physiol. 2006;572:477-92.

10. Knobloch M, Farinelli M, Konietzko U, Nitsch RM, Mansuy IM. Abeta oligomer-mediated long-term potentiation impairment involves protein phosphatase 1-dependent mechanisms. J Neurosci. 2007;27:7648-53.

11. Korshavn KJ, Satriano C, Lin Y, Zhang R, Dulchavsky M, Bhunia A, Ivanova MI Lee YH, La Rosa C, Lim MH, Ramamoorthy A. Reduced lipid bilayer thickness regulates the aggregation and cytotoxicity of amyloid-beta. J Biol Chem. 2017:292:4638-50

12. Kotler SA, Walsh P, Brender JR, Ramamoorthy A. Differences between amyloid-beta aggregation in solution and on the membrane: insights into elucidation of the mechanistic details of Alzheimer's disease. Chem Soc Rev. 2014:43:6692-700

13. Matsuzaki K. How do membranes initiate Alzheimer's disease? Formation of toxic amyloid fibrils by the amyloid beta-protein on ganglioside clusters. Acc Chem Res. 2014:47:2397-404.

14. Lannfelt L, Moller C, Basun H, Osswald G, Sehlin D, Satlin A, Logovinsky V, Gellerfors P. Perspectives on future Alzheimer therapies: amyloid-beta protofibrils - a new target for immunotherapy with BAN2401 in Alzheimer's disease. Alzheimers Res Ther. 2014;6:16

15. Sehlin D, Englund H, Simu B, Karlsson M, Ingelsson M, Nikolajeff F, Lannfelt $L$, Pettersson FE. Large aggregates are the major soluble Abeta species in AD brain fractionated with density gradient ultracentrifugation. PLoS One. 2012:7:e32014

16. Lord A, Gumucio A, Englund H, Sehlin D, Sundquist VS, Soderberg L, Moller C, Gellerfors P, Lannfelt L, Pettersson FE, Nilsson LN. An amyloid-beta protofibril-selective antibody prevents amyloid formation in a mouse model of Alzheimer's disease. Neurobiol Dis. 2009;36:425-34.

17. Orre M, Kamphuis W, Osborn LM, Melief J, Kooijman L, Huitinga I, Klooster J, Bossers K, Hol EM. Acute isolation and transcriptome characterization of cortical astrocytes and microglia from young and aged mice. Neurobiol Aging. 2014;35:1-14

18. Sofroniew MV, Vinters HV. Astrocytes: biology and pathology. Acta Neuropathol. 2010;119:7-35. 
19. Eroglu C, Barres BA. Regulation of synaptic connectivity by glia. Nature. 2010;468:223-31.

20. Verkhratsky A, Nedergaard M, Hertz L. Why are astrocytes important? Neurochem Res. 2015;40:389-401.

21. Pekny M, Wilhelmsson U, Pekna M. The dual role of astrocyte activation and reactive gliosis. Neurosci Lett. 2014;565:30-8.

22. Neumann M, Kahle PJ, Giasson Bl, Ozmen L, Borroni E, Spooren W, Muller V, Odoy S, Fujiwara H, Hasegawa M, et al. Misfolded proteinase K-resistant hyperphosphorylated alpha-synuclein in aged transgenic mice with locomotor deterioration and in human alpha-synucleinopathies. J Clin Invest. 2002;110:1429-39.

23. Rappold PM, Tieu K. Astrocytes and therapeutics for Parkinson's disease. Neurotherapeutics. 2010;7:413-23.

24. Jones RS, Minogue AM, Connor TJ, Lynch MA. Amyloid-beta-induced astrocytic phagocytosis is mediated by CD36, CD47 and RAGE. J Neurolmmune Pharmacol. 2013;8:301-11.

25. Chung WS, Clarke LE, Wang GX, Stafford BK, Sher A, Chakraborty C, Joung J, Foo LC, Thompson A, Chen C, et al. Astrocytes mediate synapse elimination through MEGF10 and MERTK pathways. Nature. 2013;504:394-400.

26. Chang GH, Barbaro NM, Pieper RO. Phosphatidylserine-dependent phagocytosis of apoptotic glioma cells by normal human microglia, astrocytes, and glioma cells. Neuro-Oncology. 2000;2:174-83.

27. Magnus T, Chan A, Linker RA, Toyka KV, Gold R. Astrocytes are less efficient in the removal of apoptotic lymphocytes than microglia cells: implications for the role of glial cells in the inflamed central nervous system. J Neuropathol Exp Neurol. 2002;61:760-6.

28. Sokolowski JD, Nobles SL, Heffron DS, Park D, Ravichandran KS, Mandell JW. Brain-specific angiogenesis inhibitor-1 expression in astrocytes and neurons: implications for its dual function as an apoptotic engulfment receptor. Brain Behav Immun. 2011:25:915-21.

29. Chabrier MA, Blurton-Jones M, Agazaryan AA, Nerhus JL, Martinez-Coria $H$, LaFerla FM. Soluble abeta promotes wild-type tau pathology in vivo. J Neurosci. 2012;32:17345-50.

30. Fellner L, Irschick R, Schanda K, Reindl M, Klimaschewski L, Poewe W, Wenning GK, Stefanova N. Toll-like receptor 4 is required for alpha-synuclein dependent activation of microglia and astroglia. Glia. 2013;61:349-60.

31. Sollvander S, Nikitidou E, Brolin R, Soderberg L, Sehlin D, Lannfelt L, Erlandsson A. Accumulation of amyloid-beta by astrocytes result in enlarged endosomes and microvesicle-induced apoptosis of neurons. Mol Neurodegener. 2016;11:38.

32. Nielsen HM, Mulder SD, Belien JA, Musters RJ, Eikelenboom P, Veerhuis R. Astrocytic $A$ beta 1-42 uptake is determined by $A$ beta-aggregation state and the presence of amyloid-associated proteins. Glia. 2010;58:1235-46.

33. Nagele RG, D'Andrea MR, Lee H, Venkataraman V, Wang HY. Astrocytes accumulate $\mathrm{A}$ beta 42 and give rise to astrocytic amyloid plaques in Alzheimer disease brains. Brain Res. 2003;971:197-209.

34. Magnusson K, Sehlin D, Syvanen S, Svedberg MM, Philipson O, Soderberg L, Tegerstedt K, Holmquist M, Gellerfors P, Tolmachev V, et al. Specific uptake of an amyloid-beta protofibril-binding antibody-tracer in AbetaPP transgenic mouse brain. J Alzheimers Dis. 2013;37:29-40.

35. Sehlin D, Sollvander S, Paulie S, Brundin R, Ingelsson M, Lannfelt L, Pettersson FE, Englund $\mathrm{H}$. Interference from heterophilic antibodies in amyloid-beta oligomer ELISAs. J Alzheimers Dis. 2010;21:1295-301.

36. Davis AA, Temple S. A self-renewing multipotential stem cell in embryonic rat cerebral cortex. Nature. 1994:372:263-6.

37. Johe KK, Hazel TG, Muller T, Dugich-Djordjevic MM, McKay RD. Single factors direct the differentiation of stem cells from the fetal and adult central nervous system. Genes Dev. 1996;10:3129-40.

38. Ravin R, Hoeppner DJ, Munno DM, Carmel L, Sullivan J, Levitt DL, Miller JL, Athaide C, Panchision DM, McKay RD. Potency and fate specification in CNS stem cell populations in vitro. Cell Stem Cell. 2008;3:670-80.

39. Hultqvist G, Syvanen S, Fang XT, Lannfelt L, Sehlin D. Bivalent brain shuttle increases antibody uptake by monovalent binding to the transferrin receptor. Theranostics. 2017;7:308-18.

40. Olsen M, Aguilar X, Sehlin D, Fang XT, Antoni G, Erlandsson A, Syvanen S. Astroglial responses to amyloid-beta progression in a mouse model of Alzheimer's disease. Mol Imaging Biol. 2018;

41. Stenh C, Englund H, Lord A, Johansson AS, Almeida CG, Gellerfors P, Greengard P, Gouras GK, Lannfelt L, Nilsson LN. Amyloid-beta oligomers are inefficiently measured by enzyme-linked immunosorbent assay. Ann Neurol 2005:58:147-50
42. Sehlin D, Hedlund M, Lord A, Englund H, Gellerfors P, Paulie S, Lannfelt L, Pettersson FE. Heavy-chain complementarity-determining regions determine conformation selectivity of anti-abeta antibodies. Neurodegener Dis. 2011;8: $117-23$.

43. Englund $H$, Sehlin D, Johansson AS, Nilsson LN, Gellerfors P, Paulie S, Lannfelt L, Pettersson FE. Sensitive ELISA detection of amyloid-beta protofibrils in biological samples. J Neurochem. 2007;103:334-45.

44. Appelqvist $H$, Waster $P$, Kagedal $K$, Ollinger $K$. The lysosome: from waste bag to potential therapeutic target. J Mol Cell Biol. 2013;5:214-26.

45. Nixon RA, Yang DS, Lee JH. Neurodegenerative lysosomal disorders: a continuum from development to late age. Autophagy. 2008;4:590-9.

46. Mawuenyega KG, Sigurdson W, Ovod V, Munsell L, Kasten T, Morris JC, Yarasheski KE, Bateman RJ. Decreased clearance of CNS beta-amyloid in Alzheimer's disease. Science. 2010;330:1774.

47. Englund H, Anneren G, Gustafsson J, Wester U, Wiltfang J, Lannfelt L, Blennow K, Hoglund K. Increase in beta-amyloid levels in cerebrospinal fluid of children with Down syndrome. Dement Geriatr Cogn Disord. 2007;24: 369-74.

48. Tucker S, Moller C, Tegerstedt K, Lord A, Laudon H, Sjodahl J, Soderberg L, Spens E, Sahlin C, Waara ER, et al. The murine version of BAN2401 (mAb158) selectively reduces amyloid-beta protofibrils in brain and cerebrospinal fluid of tg-ArcSwe mice. J Alzheimers Dis. 2015:43:575-88.

49. Logovinsky V, Satlin A, Lai R, Swanson C, Kaplow J, Osswald G, Basun H, Lannfelt L. Safety and tolerability of BAN2401-a clinical study in Alzheimer's disease with a protofibril selective Abeta antibody. Alzheimers Res Ther. 2016:8:14.

50. Bard F, Barbour R, Cannon C, Carretto R, Fox M, Games D, Guido T, Hoenow K, Hu K, Johnson-Wood K, et al. Epitope and isotype specificities of antibodies to beta-amyloid peptide for protection against Alzheimer's disease-like neuropathology. Proc Natl Acad Sci U S A. 2003;100:2023-8.

51. Sazinsky SL, Ott RG, Silver NW, Tidor B, Ravetch JV, Wittrup KD. Aglycosylated immunoglobulin G1 variants productively engage activating Fc receptors. Proc Natl Acad Sci U S A. 2008;105:20167-72.

52. Kim J, Basak JM, Holtzman DM. The role of apolipoprotein E in Alzheimer's disease. Neuron. 2009;63:287-303.

53. Jonsson T, Atwal JK, Steinberg S, Snaedal J, Jonsson PV, Bjornsson S, Stefansson $\mathrm{H}$, Sulem P, Gudbjartsson D, Maloney J, et al. A mutation in APP protects against Alzheimer's disease and age-related cognitive decline. Nature. 2012:488:96-9.

54. Jin M, Shepardson N, Yang T, Chen G, Walsh D, Selkoe DJ. Soluble amyloid beta-protein dimers isolated from Alzheimer cortex directly induce Tau hyperphosphorylation and neuritic degeneration. Proc Natl Acad Sci U S A. 2011;108:5819-24.

55. Leabman MK, Meng YG, Kelley RF, DeForge LE, Cowan KJ, lyer S. Effects of altered FcgammaR binding on antibody pharmacokinetics in cynomolgus monkeys. MAbs 2013;5:896-903.

56. Villemagne VL, Perez KA, Pike KE, Kok WM, Rowe CC, White AR, Bourgeat P, Salvado O, Bedo J, Hutton CA, et al. Blood-borne amyloid-beta dimer correlates with clinical markers of Alzheimer's disease. J Neurosci. 2010;30: 6315-22.

57. Bacskai BJ, Kajdasz ST, McLellan ME, Games D, Seubert P, Schenk D, Hyman BT. Non-Fc-mediated mechanisms are involved in clearance of amyloid-beta in vivo by immunotherapy. J Neurosci. 2002;22:7873-8.

58. Das P, Howard V, Loosbrock N, Dickson D, Murphy MP, Golde TE. Amyloidbeta immunization effectively reduces amyloid deposition in FcRgamma-/knock-out mice. J Neurosci. 2003;23:8532-8.

59. Loov C, Erlandsson A. Lysosomal Acidification in Cultured Astrocytes Using Nanoparticles. Methods Mol Biol. 2017;1594:165-77.

60. Gustafsson G, Lindstrom V, Rostami J, Nordstrom E, Lannfelt L, Bergstrom J, Ingelsson M, Erlandsson A. Alpha-synuclein oligomer-selective antibodies reduce intracellular accumulation and mitochondrial impairment in alphasynuclein exposed astrocytes. J Neuroinflammation. 2017;14:241. 